\title{
Tingkat Pengetahuan Dengan Sikap dan Praktik Perawat Dalam Implementasi Patient Safety : Risiko Jatuh di RSUD Dr. Soehadi Priedjonegoro Sragen
}

\author{
Wahyuningsih Safitri ${ }^{1)}$ Atiek Murharyati ${ }^{2)}$ \\ ${ }^{1)}$ Program Studi Sarjana Keperawatan STIKes Kusuma Husada Surakarta \\ ${ }^{2)}$ Program Studi Sarjana Keperawatan STIKes Kusuma Husada Surakarta \\ ${ }^{1)}$ wahyuningsihsafitri@gmail.com, ${ }^{2)}$ amorhayati@yahoo.com
}

\begin{abstract}
ABSTRAK
Patient Safety merupakan proses dalam rumah sakit yang memberikan pelayanan pasien yang lebih aman. Patient Safety salah satunya risiko jatuh kejadian yang harus dihindari di Rumah Sakit sehingga praktik perawat dalam implementasi patient safety harus dilakukan. Tujuan dari penelitian ini untuk mengetahui hubungan tingkat pengetahuan dengan sikap dan praktik perawat dalam implementasi patient safety : risiko jatuh Di RSUD Dr. Soehadi Priedjonegoro Sragen. Penelitian ini merupakan penelitian kuantitatif non eksperimental dengan desain penelitian cross sectional. Pengambilan sampel dengan cara Proportionate Stratified Random Sampling, sejumlah 116 responden. Tingkat pengetahuan perawat mayoritas pengetahuan baik sebanyak 52 responden $(44,8 \%)$, sikap perawat baik sebanyak 69 responden (59,5\%), Praktik perawat dalam implementasi patient safety : risiko jatuh mayoritas responden melakukan praktik perawat sebanyak 88 responden $(75,9 \%)$. Analisa data menggunakan uji chi square.

Kesimpulan dari penelitian ini adalah adanya hubungan tingkat pengetahuan dengan sikap dan praktik perawat dalam implementasi patient safety : risiko jatuh Di RSUD Dr. Soehadi Priedjonegoro Sragen $(p=0,001)$.
\end{abstract}

Kata Kunci : Tingkat Pengetahuan, Sikap, Praktik Perawat

\section{ABSTRACT}

Patient Safety is a process in hospitals that provide patient services more secure. One which is related to patient safety, namely: the risk of falling. Such an incidence must be avoided at hospitals so that the nursing practice in the implementation of patient safety must be conducted. The objective of this research is to investigate the correlation between the knowledge level with attitude and the nursing practice in the implementation of patient safety: the risk falling at Dr. Soehadi Local General Hospital of Priedjonegoro Sragen. This research used the quantitative nonexperimental research method with the cross-sectional approach. Proportionate stratified random sampling was used to determine its samples. The samples consisted of 116 respondents. The data of the research were analyzed by using the Spearman's Rank Correlation at the significance value of 0.05. 52 respondents (44.8\%) had a good knowledge level, 69 respondents $(59.5 \%)$ had a good attitude level and 88 respondents (75.9\%) conducted the nursing practice in the implementation of patient safety: the risk of falling. Data analysis with chi square test. Thus, there was a strong correlation between the knowledge level with attitude and the nursing practice in the implementation of patient safety: the risk of falling at Dr.Soehadi Priedjonegoro Local General Hospital of Sragen.

Keywords : Knowledge level, attitude, nursing practice 


\section{PENDAHULUAN}

Keselamatan pasien membuat asuhan pasien lebih aman yang meliputi assement resiko, identifikasi dan pengelolaan hal yang berhubungan dengan resiko pasien, pelaporan dan analisis insiden, kemampuan belajar dari insiden, dan tindak lanjutnya serta implementasi solusi untuk meminimalkan timbulnya resiko dan mencegah terjadinya cedera yang disebabkan oleh kesalahan akibat melaksanakan suatu tindakan atau tidak mengambil tindakan yang seharusnya diambil (Kemenkes RI, 2011). Menurut Soehatman (2009), manajemen pengendalian resiko salah satunya pencegahan kesalahan yang dilakukan oleh perawat. Kecelakaan dapat terjadi karena faktor manusia, saran, proses dan prosedur.

Keselamatan pasien terkait injury didefinisikan terbebas dari accidental injury dengan menjamin keselamatan pasien melalui penetapan sistem operasional, meminimalisasi kemungkinan kesalahan, dan meningkatkan pencegahan agar kecelakaan tidak terjadi dalam proses pelayanan (Elfrida, 2011).

Sasaran keselamatan pasien dalam akreditasi yang dilakukan oleh KARS (Komite Akreditasi Rumah Sakit) mengacu pada JCI serta PERMENKES Nomor 1691 Tahun 2011 tentang Keselamatan Pasien di Rumah Sakit pada Pasal 8 Ayat 2 menyebutkan bahwa sasaran keselamatan pasien terdiri 6 poin meliputi ketepatan identifikasi pasien, peningkatan komunikasi efektif, peningkatan keamanan obat yang perlu diwaspadaan, kepastian tepat lokasi, tepat prosedur, tepat pasien operasi; pengurangan risiko infeksi terkait pelayanan kesehatan serta pengurangan risiko jatuh (Kemenkes, 2011).

Hasil penelitian Barbara, dkk (2015) jumlah pasien jatuh di lima kota besar di Kanada sebanyak 7.592 pasien rawat inap yang jatuh pada tahun 2009 sampai 2014 dan waktu tersering pasien jatuh antara pukul 10.00 dan 12.00 malam. Prosentase kejadian jatuh di Rumah Sakit umum sebanyak 96,67\% dan kejadian di Rumah sakit khusus sebanyak $33,3 \%{ }^{6}$. Pada saat ini pelaporan insiden keselamatan pasien berdasarkan provinsi pada tahun 2010 ditemukan Jawa Barat 33,33\%, Jawa Tengah 20\%, dan Jawa Timur 3,33\% (Komite Keselamatan Pasien RS, 2010).

Menurut Stanley (2006), dampak dari ketidak terlaksanaannya penerapan pasien safety resiko jatuh jika pasien mengalami jatuh mengakibatkan berbagai jenis cidera, kerusakan fisik, dan psikologis. Dampak psikologis dari resiko jatuh adalah walaupun cidera fisik tidak terjadi, syok setelah jatuh dan rasa takut akan jatuh lagi dapat memiliki banyak konsekuensi termasuk ansietas, hilangnya rasa percaya diri, pembatasan dalam aktivitas sehari-hari, dan takut akan jatuh.

Di Inggris dan Wales, sekitar 152.000 jatuh dilaporkan di rumah sakit akut setiap tahun, dengan lebih dari 26.000 dilaporkan dari unit kesehatan mental dan 28.000 dari rumah sakit masyarakat. Dalam Kongres Persi XXI di Jakarta pada tanggal 8 November 2012 melaporkan bahwa kejadian pasien jatuh di Indonesia pada bulan Januari sampai September 2012 sebesar 14\%. Hal ini membuat persentasi pasien jatuh termasuk ke dalam lima besar insiden medis selain medicine error (Komariah, 2012).

Pengetahuan perawat merupakan hal yang berhubungan dengan komitmen yang sangat diperlukan dalam upaya membangun budaya keselamatan pasien (Cahyono, 2008). Pengetahuan adalah salah satu faktor dari manusia yang berpengaruh terhadap kejadian nyaris cidera dan kejadian tidak diharapkan. Patient Safety merupakan proses dalam rumah sakit yang memberikan pelayanan pasien yang lebih aman. Termasuk di dalamnya assessment risiko, identifikasi, dan manajemen risiko terhadap pasien, pelaporan dan analisis insiden, kemampuan untuk belajar dan menindaklanjuti insiden, dan menerapkan solusi untuk mengurangi serta meminimalisir timbulnya risiko (Ariyani 2008).

Hasil penelitian Nanda dkk (2011) mengatakan pengetahuan dan karakteristik perawat (umur, masa kerja, dan pelatihan) memiliki hubungan secara bermakna dengan penerapan sikap dengan 16 orang $(33,3 \%)$ mempunyai sikap kurang mendukung tentang program keselamatan pasien. Penelitian Ariyani (2008) menyimpulkan bahwa pengetahuan perawat pelaksana tentang konsep patient safety baik dan sikap mendukung penerapan program patient safety tinggi. Perilaku perawat yang tidak menjaga keselamatan pasien berkontribusi terhadap insiden keselamatan pasien. 
Hasil studi pendahuluan di RSUD Dr. Soehadi Priedjonegoro Sragen pada Bulan Januari 2017 jumlah pasien dengan risiko jatuh yaitu 250 orang. Risiko jatuh terjadi pada lansia, balita, penderita vertigo, anemia, stroke, hipertensi, pasien kecelakaan lalu lintas.

Tujuan penelitian ini adalah untuk mengetahui hubungan tingkat pengetahuan dengan sikap dan praktik perawat dalam implementasi patient safety : risiko jatuh Di RSUD Dr. Soehadi Priedjonegoro Sragen.

\section{METODE}

Penelitian ini menggunakan pendekatan kuantitatif dengan desain cross sectional, yaitu penelitian yang bertujuan untuk mengetahui hubungan tingkat pengetahuan dengan sikap dan praktik perawat dalam implementasi patient safety : risiko jatuh diidentifikasi pada satu satuan waktu. Penelitian ini dilakukan dari bulan Juni - Juli 2017 di Rumah Sakit Umum Daerah Dr. Soehadi Prijonegoro Sragen. Teknik sampling penelitian ini ialah Proportionate Stratified Random Sampling. Peneliti melakukan pengumpulan data pada 116 responden. Pengumpulan data dengan memberikan kuesioner. Uji hipotesis yang digunakan dalam penelitian ini adalah cross sectional dengan chi square untuk menganalisis ada tidaknya hubungan antara tingkat pengetahuan dengan sikap dan praktik perawat dalam implementasi patient safety : risiko jatuh.

HASIL

Tabel 1. Hubungan antara pengetahuan dengan sikap perawat dalam implementasi patient safety : risiko jatuh Di RSUD Dr. Soehadi Priedjonegoro Sragen (n:116)

\begin{tabular}{|c|c|c|c|c|}
\hline & & \multicolumn{2}{|c|}{ Sikap } & \multirow{2}{*}{$\sum$} \\
\hline & & Kurang & Baik & \\
\hline \multirow[t]{2}{*}{ Pengetahuan } & Kurang & 18 & 34 & 52 \\
\hline & Baik & 24 & 40 & 64 \\
\hline \multicolumn{2}{|c|}{ Total } & 42 & 74 & 116 \\
\hline \multicolumn{5}{|c|}{$\mathrm{P}$ value 0,001} \\
\hline
\end{tabular}

Tabel 1 menunjukkan bahwa diantara 64 perawat dengan pengetahuan baik, sebanyak 24 perawat akan memiliki sikap dalam implementasi patient safety: risiko jatuh kurang, sedangkan diantara 52 perawat dengan pengetahuan kurang, ada 18 perawat akan memiliki sikap dalam implementasi patient safety : risiko jatuh kurang.

Tabel silang diatas juga menunjukkan uji hipotesis dengan chi square yang didapatkan hasil $p$ value 0,001 kurang dari taraf signifikansi 0,05 sehingga $\mathrm{H}_{0}$ ditolak yang berarti ada hubungan hubungan antara pengetahuan dengan sikap perawat dalam implementasi patient safety : risiko jatuh

Tabel 2. Hubungan antara pengetahuan dengan perilaku perawat dalam implementasi patient safety : risiko jatuh Di RSUD Dr. Soehadi Priedjonegoro Sragen (n:116)

\begin{tabular}{|c|c|c|c|c|}
\hline & \multicolumn{2}{|c|}{ Perilaku } & \multirow[t]{2}{*}{$\sum$} \\
\hline & & Kurang & Baik & \\
\hline \multirow[t]{2}{*}{ Pengetahuan } & Kurang & 14 & 30 & 44 \\
\hline & Baik & 20 & 52 & 72 \\
\hline \multicolumn{2}{|c|}{ Total } & 34 & 82 & 116 \\
\hline \multicolumn{5}{|c|}{$\mathrm{p}$ value 0,000} \\
\hline
\end{tabular}

Tabel 2 menunjukkan bahwa diantara 72 perawat dengan pengetahuan baik, sebanyak 20 perawat akan memiliki perilaku dalam implementasi patient safety: risiko jatuh kurang, sedangkan diantara 44 perawat dengan pengetahuan kurang, ada sebanyak 14 perawat akan memiliki perilaku dalam implementasi patient safety : risiko jatuh kurang.

Tabel silang diatas juga menunjukkan uji hipotesis dengan chi square yang didapatkan hasil $p$ value 0,000 kurang dari taraf signifikansi 0,05 sehingga $\mathrm{H}_{0}$ ditolak yang berarti ada hubungan Hubungan antara pengetahuan dengan sikap perawat dalam implementasi patient safety : risiko jatuh

\section{PEMBAHASAN}

Pengetahuan merupakan domain yang sangat penting untuk terbentuknya tindakan seseorang. Pengetahuan diperlukan sebagai dukungan dalam menumbuhkan rasa percaya diri maupun sikap dan perilaku, sehingga pengetahuan merupakan fakta yang mendukung tindakan seseorang ${ }^{13}$. Pengetahuan seseorang tentang suatu objek mengandung dua aspek, yaitu aspek positif dan negatif. Kedua aspek ini akan menentukan sikap seseorang semakin banyak aspek positif dan objek yang diketahui, maka akan menimbulkan sikap makin positif terhadap objek tertentu (Wawan \& Dewi, 2011). 
Hasil penelitian menunjukkan pengetahuan responden yang masih kurang dapat terjadi karena dipengaruhi oleh faktor internal dan faktor eksternal. Faktor eksternal dapat diperoleh dari sosialisasi dari RumahSakit tentang patient safety. Peneliti menyimpulkan bahwa pengetahuan merupakan hal yang sangat penting yang harus dimiliki oleh seorang perawat.Seorang perawat yang memiliki pengetahuan baik, maka perawat tersebut diharapkan mampu melakukan melaksanakan semua tugasnya secara efektif dan efisien, sehingga kinerja pun semakin membaik.

Pengetahuan perawat tentang patient safety merupakan hal yang penting, karena jika pengetahuan perawat tentang patient safety kurang maka jelas ini akan berpengaruh terhadap kinerja perawat itu sendiri dalam penerapan patient safety di Rumah Sakit (Notoatmojo, 2007)

Hasil penelitian pendukung penelitian ini adalah penelitian di RSUD Prof. Dr. Hi. Aloei Saboe Kota Gorontalo menunjukkan sebanyak 45 responden $(88,2 \%)$ yang memiliki pengetahuan baik dan penerapan patient safety juga baik, sedangkan yang memiliki pengetahuan baik dan penerapan patient safety kurang ada 1 responden (2\%). Sementara yang memiliki pengetahuan kurang dan penerapan patient safety kurang ada 5 responden $(9,8 \%)$ (Gunibala MK, dkk, 2015).

Penelitian Bawellle dkk tahun 2013 menunjukkan $95 \%$ perawat mempunyai sikap baik terhadap pelaksanaan keselamatan pasien (patient safety) di Rumah Sakit dimana sikap akan mempengaruhi keterlaksananya penerapan patient safety. Patient safety merupakan suatu sistem dimana rumah sakit membuat asuhan yang aman bagi kliennya. Sistem ini mencegah terjadinya cidera yang disebabkan oleh kesalahan akibat melaksanakan suatu tindakan4. Patient safety sangat diperlukan untuk memenuhi kebutuhan dasar manusia yang harus dipenuhi oleh rumah sakit saat melakukan asuhan keperawatan yang aman bagi kliennya dan mencegah terjadinya cidera pada pasien (Bawelle, 2013).

Praktik atau perilaku adalah tindakan atau aktivitas manusia yang memiliki bentangan yang sangat luas. Hal ini relevan dengan pendapat yang disampaikan Notoatmodjo (2012) bahwa perilaku merupakan seluruh kegiatan atau aktivitas manusia, baik yang diamati secara langsung, maupun yang tidak diamati dari pihak luar ${ }^{17}$. Penelitian ini didukung penelitian Jaladara (2015) menunjukkan ada hubungan yang antara pengetahuan dan praktik, dalam hal ini terkait dengan keselamatan pasien (patient safety) ${ }^{18}$.

Penelitian oleh Rahman tahun 2008 menjelaskan bahwa pengetahuan seseorang dapat diperoleh melalui pelatihan. Dengan pengetahuan yang dimiliki seseorang akan mendasari perilaku dalam memberikan tindakan dapat dilakukan dengan lebih efektif ${ }^{19}$.Penelitian pendukung lain dilakukan oleh Lestari tahun 2013 menunjukkan ada hubungan antara pengetahuan perawat dengan penerapan patient safety pada pasien stroke di RSU PKU Muhammadiyah Bantul ${ }^{20}$.

\section{KESIMPULAN}

Kesimpulan dari penelitian ini adalah terdapat hubungan antara tingkat pengetahuan dengan sikap dan praktik perawat dalam implementasi patient safety : risiko jatuh.

\section{SARAN}

Saran bagi peneliti selanjutnya, diharapkan dapat menggali lebih dalam lagi tentang faktor-faktor yang mempengaruhi implementasi patient safety : risiko jatuh dengan menambahkan beberapa variabel. Selain itu, perlu dilakukan kajian lebih mendalam lagi tentang patient safety.

\section{DAFTAR PUSTAKA}

Kementerian Kesehatan RI. (2011). Pedoman Penyelenggaraan Keselamatan Pasien di Rumah Sakit.

Ramli, Soehatman. (2009). Sistem manajemen keselamatan dan kesehatan kerja. Jakarta: Dian rakyat

Elrifda S. (2011). Budaya Patient Safety dan Karakteristik Kesalahan Pelayanan: Implikasi Kebijakan di Salah Satu Rumah Sakit di Kota Jambi. $J$ Kesehatan Masyarakat Nas. 2011;6, No. 2(Oktober):67-76.

Kemenkes. (2011). Peraturan Menteri Kesehatan Republik Indonesia Nomor 1691/Menkes/Per/VIII/2011 Tentang Keselamatan Pasien Rumah Sakit.

Barbara J. Watson , Alan W. Salmoni, Aleksandra A. Zecevic. (2015). Falls in an acute care hospital as reported in the adverse event management system. 
ISSN 1927-6990 E-ISSN 1927-7008. 2015, Vol. 4, No. 4. www.sciedu.ca/jha

Departemen Kesehatan Republik Indonesia. (2008). Panduan Nasional Keselamatan Pasien Rumah Sakit (Patient Safety). Jakarta: KKPRS

Komite Keselamatan Pasien Rumah Sakit. (2010). Sembilan Solusi Live- Saving Keselamatan Pasien Rumah Sakit.

Stanley,M.,\&Beare,P.G. (2006). Buku Ajar Keperawatan Gerontik. Jakarta: EGC.

Komariah, S. (2012). Peran Keperawatan Dalam Menurunkan Insiden Keselamatan Pasien [online] http://manajemenrumahsakit.net/files/si ti\%20komariah\%20_PERAN\%20KEP \%20DALAM\%20IKP.pdf

Cahyono, J.B. Suhardjo B. (2008). Membangun Budaya Keselamatan Pasien dalam Praktek Kedokteran. Yogyakarta: Kanisius.

Ariyani. (2008). Analisis Pengetahuan Dan Motivasi Perawat Yang Mempengaruhi Sikap Mendukung Penerapan Program Patien Safety Di Instalasi Perawatan Intensif RSUD DR Moewardi Surakarta. Tesis. Program Pasca Sarjana UNDIP. Dipublikasikan.

Nanda Wulandari, Ratna Setyaningrum, Musafaah. (2011). Hubungan karakteristik dan pengetahuan perawat dengan sikap mendukung penerapan program kesehatan di RSUD Banjarbaru. Fakultas Kedokteran Universitas Lambung Mangkurat

Notoatmodjo, S. (2007). Pendidikan dan Perilaku kesehatan. Cetakan 2 Jakarta:Rineka cipta

WawanA\&DewiM. (2011). Teori Dan Pengukuran Pengetahuan, Sikap dan perilaku. Yogyakarta:Nuha Medika

Gunibala MT, Yusuf ZK, Y.Dulahu W. (2015). Hubungan Pengetahuan Dan Sikap Perawat Dengan Penerapan Patient Safety Di Rsud Prof. Dr. H. Aloei Saboe Kota Gorontalo

Bawelle, Selleya Cintya dkk. (2013). Hubungan Pengetahuan Dan Sikap Perawat Dengan Pelaksanaan Keselamatan Pasien Di Ruang Rawat Inap RSUD Liun Kendage Tahuna. Universitas Sam Ratulangi Manado
Notoatmodjo, S. (2012). Promosi Kesehatan dan Perilaku Kesehatan. Jakarta: Rineka Cipta

Vena Jaladara, Siswi Jayanti, Ekawati.(2015). Hubungan tingkat pengetahuan dan praktik perawat mengenai keselamatan pasien (patient safety) di instalasi gawat darurat rs x semarang. Jurnal kesehatan masyarakat .(e-Journal) Volume 3, Nomor 1, Januari 2015 (ISSN: 23563346) http://ejournals1.undip.ac.id/index.php/jkm

Rahman, N. (2008). Pengetahuan Perawat Tentang Kegawatan Nafas Dan Tindakan Resusitasi Pada Neonatus Yang Mengalami Kegawatan di Ruang NICU, Perinatologi dan Anak RSUD Gunung Jati Cirebon.

Lestari, W. (2013). Hubungan pengetahuan perawat tentang patient safety dengan penerapan patient safety pada pasin stroke di rawat inap di RS PKU Muhammadiyah Bantul. Sekolah Tinggi Ilmu Kesehatan 'Aisyiyah Yogyakarta. 